\title{
Sales Profession and Professionals in the Age of Digitization and Artificial Technologies: Concepts, Priorities, and Questions
}

\author{
Jagdip Singh ${ }^{1 \mathrm{a}}$, Karen Flaherty ${ }^{2 \mathrm{a}}$ and Ravipreet S. Sohi ${ }^{3 \mathrm{a}}$ \\ Dawn Deeter-Schmelz ${ }^{4 b}$, Johannes Habel ${ }^{5 b}$, Kenneth Le Meunier-FitzHugh ${ }^{6 b}$, \\ Avinash Malshe $^{7 b}$, Ryan Mullins ${ }^{8 b}$, Vincent Onyemah ${ }^{9 b}$
}

${ }^{1}$ AT\&T Professor of Marketing, Case Western Reserve University

${ }^{2}$ Professor of Marketing, Oklahoma State University

${ }^{3}$ Professor and Robert D. Hays Distinguished Chair of Sales Excellence, University of NebraskaLincoln

${ }^{4}$ Professor \& J.J. Vanier Distinguished Chair of Relational Selling and Marketing, Kansas State University

${ }^{5}$ Associate Professor of Marketing, ESMT Berlin

${ }^{6}$ Senior Lecturer in Marketing, University of East Anglia

${ }^{7}$ Professor of Marketing, University of St. Thomas, MN

${ }^{8}$ Associate Professor of Marketing, Clemson University

${ }^{9}$ Associate Professor of Marketing, Babson College

${ }^{a}$ Team Lead. Coordinated the efforts of their team members to workshop ideas and develop initial drafts. Subsequently, teams leads worked together to develop a coherent and integrated article for submission. Team leads contributed equally to the development of the final submission.

bIndividual team member. Team members contributed equally and are listed alphabetically by last name. 


\title{
Sales Profession and Professionals in the Age of Digitization and Artificial Technologies: Concepts, Priorities, and Questions
}

\begin{abstract}
Recognizing the rapid advances in sales digitization and artificial intelligence technologies, we develop the concepts, priorities, and questions to help guide future research and practice in the field of personal selling and sales management. Our analyses reveals that the influence of sales digitalization technologies, which includes digitization and artificial intelligence, is likely to be more significant and more far-reaching than previous sales technologies. To organize our analysis of this influence, we discuss the opportunities and threats that the sales digitalization technologies pose for (a) sales profession in terms of its contribution for creating value for customers, organizations, and society and (b) sales professionals, both in terms of employees-inorganizations and individuals-as-self, seeking growth, fulfillment, and status in the functions they serve and roles they live. We summarize our discussion by detailing specific research priorities and questions that warrant further study and development by researchers and practitioners alike.
\end{abstract}




\section{Sales Profession and Professionals in the Age of Digitization and Artificial Technologies: Concepts, Priorities, and Questions}

Rapid advances in digital technologies, popularly referred to as the fourth industrial revolution (Syam and Sharma 2018), are disrupting well-established sales practices and upturning well-known sales theories, just as they are opening new and exciting opportunities for innovation and creativity in sales practice and research (Grove et al. 2018; Baumgartner, Hatami, and Valdiviesco 2016). Practitioners and scholars differ in their prognosis. For some, "selling in the future decades will be disruptive and discontinuous... such that salespeople will have to coexist with AI and other technologies" (Syam and Sharma 2018, pp. 135-136). For others, the technological advances portend a future that is a "better time [than any so far] to be in sales... [despite] the considerable shrinkage in overall number of sales jobs" because these advances will augment the sales profession with "...ethical standards, formal processes, rigorous metrics, continuous learning and a huge body of research behind it" (Trailer 2017, pp. 2-4). Differing predictions for the future of sales as a profession, and for individuals who will populate this profession, are commonplace (Cron 2017; Orlob 2017; Marshall et al. 2012). Yet, there is a lack of clarity regarding how digital technologies will shape opportunities and threats for the (a) sales profession in terms of its contribution for creating value for customers, organizations, and society and (b) sales professionals, both as employees-in-organizations and individuals-as-self, seeking growth, fulfillment, and status in the functions they serve and roles they live.

This preceding gap motivates this paper to develop priorities and directions for future research that provides robust and meaningful insights to guide sales research and practice. Three aspects of our contribution are noteworthy: (a) unconventional approach, (b) multi-faceted consideration, and (c) comprehensive development. We outline each in turn. 
First, our approach is based on team-based workshopping and a collaborative process that emerged from the "Setting the Research Agenda in Sales" session at the 2018 AMA New Horizons Faculty Consortium in Selling and Sales Management. Led by Karen Flaherty, Jagdip Singh, and Ravi Sohi, consortium faculty worked in teams to workshop three broad themes, each illustrated by discussion questions and suggestions (see below). Teams were encouraged to use the discussion questions and suggestions as starting ideas:

Theme 1: Sales as a Profession and Value Creation

Consider the broader contribution of sales profession/function to value creation for customers, organizations and society in the age of exploding information (abundance but noisy), intelligence (powered by AI) and technologies (complexity and dynamic).

Theme 2: Sales as Professionals and the Organization

Consider the organizational challenges of structuring and managing the sales force in an era of intelligence and technology, with empowered and informed customers.

\section{Theme 3: Sales as a Professional and the Individual}

Consider the individual challenges of filling sales roles/functions in the age of information and intelligence-rich environments, empowered and informed customers, and intelligence and technology-embedded products/services.

This paper summarizes the resulting deliberations from the subsequent development of the ideas emerging out of the Horizons workshop. Teams deliberated over a multi-month period to advance workshop ideas, connect them to the existing literature, and distill promising research priorities and questions. After that, the team leaders coordinated their team's contributions to develop a coherent and integrated contribution. This paper is the result of these efforts.

Second, throughout the workshop, teams' deliberations adopted a multi-faceted perspective to examine the forces wrought by digital technologies, particularly AI technologies, on both the sales profession, in the spirit of the "macro" approach espoused by past researchers (Cron 2017), and the sales professional, in the spirit of the individual approach common in past 
research (Verbeke, Deitz and Verwaal 2011). Salespeople fill professional roles within organizations, and it is the latter that often define sales role requirements and responsibilities. Themes of organizational control of sales professional role, common in the studies of sales control, may appear to unify sales profession and sales professional; sales profession is an aggregated representation of what professionals who fill sales roles designed and managed by organizations do (Singh and Jayanti 2013). However, as Cron (2017) alludes, new technologies are affording possibilities of untethering the sales professional from the dominant hold of organizational control as salespeople explore new roles such as "free agent" intermediaries who source products/services to provide customer solutions, and "expert" brokers who possess unique knowledge and skills to orchestrate inter-organizational assets and resources to create value. Our position is not that going forward sales professionals will be located for the most part outside organizations; instead, an increasing plurality of professional roles will shape the sales profession, and this plurality will motivate a professionalization of the sales field, as anticipated by Trailer's (2017) observations noted above.

Third, the purpose of this paper is to chart future research directions and priorities that are motivated by the threats and opportunities from digitization and AI technologies. Interest in examining the role of sales technologies has been a robust pursuit in the literature. Past research has examined the influence of a varied set of technologies including sales CRM (Hunter and Perreault 2007), social media (Marshall et al. 2012), automation (Homburg, Wieseke, and Kuehnl 2010), and other information technologies (Ahearne, Hughes, and Schilliwaert 2007). Our paper advances this stream of work by examining technologies that go beyond the goal of automating procedural activities or supporting the relational efforts of a sales role. Specifically, these technologies enable the use of digital assets to drive new business models, and address 
customer needs more precisely (Ramaswamy and Ozcan 2018). An important component of these technologies includes supervised and unsupervised learning that permits sales artifacts (i.e., a combination of software, hardware, and sales protocols) to perform some or all the sales role autonomously (Syam and Sharma 2018). Because of its knowledge and learning capabilities, digitization and AI technologies pose a disruptive force that is likely to be more significant and pervasive than previous sales technologies. Disruptions are a source of threat, as much as they are a source of opportunity.

The workshopping effort by multiple teams, each of whom approached the themes from different directions, provides a comprehensive development of sales research directions and priorities. Figure 1 displays a guiding framework for the teams' efforts and subsequent coordination to develop a coherent and integrative paper. The three teams individually workshopped to examine three domains that are likely to be disrupted by sales digitization and AI technologies: (a) sales-as-a-profession, (b) sales-as-a-professional: organizational issues, and (c) sales-as-a-professional: individual issues. Subsequently, the team leads worked together to integrate different themes and ensure a coherent flow and development.

[Figure 1 about here]

The remainder of the paper is organized as follows. First, we clarify definitions and terminology related to digital technologies. Second, we discuss the impact of digital technologies on the value creation function for the sales profession. Third, we detail changes in organizational structure and sales interfaces resulting from digital technologies. Fourth, we consider changes in individual sales roles, knowledge, skills, and abilities resulting from new digital technologies. We offer future research priorities and questions for each section. 


\section{Definitional Issues in Sales Digital Technologies}

Before outlining sales research priorities and questions, we define concepts of digitization, AI technologies, digitalization, and digital transformation (Syam and Sharma 2018), which have sometimes been used loosely but deserve differentiation (Ramaswamy and Ozcan 2018; Ross 2017). As depicted in Table 1, digitization refers to the process of capturing, processing (e.g., converting to digits), and organizing marketing knowledge (e.g., sales interactions) to make it accessible and reliable for varied goals including customer insights, operational efficiency, customer analytics and marketing learning (Ramaswamy and Ozcan 2018). As such, digitization enables digital approaches to access, organize, store, and use salesrelated knowledge. Artificial intelligence technologies concern learning (supervised or unsupervised) that permits sales artifacts (software, hardware, and sales protocols) to perform some or the entire sales role autonomously (Syam and Sharma 2018). As such, artificial intelligence enables digital approaches for tracking, assimilating, and integrating sales-related learning. Together, digital technologies for knowledge and learning promote the creation of new strategies and novel opportunities to serve customers, which we refer to as digitalization (Brennen and Kreiss 2014). Finally, digital transformation goes beyond merely improving customer outcomes in existing business models, and encompasses the application of digital technologies to existing company assets as a means to improve competencies and rethink the value proposition of the firm (Newman 2017). A digital transformation requires digitalization, and digitalization requires mobilization of digitization and AI technologies (cf. Ramaswamy and Ozcan 2018; Ross 2017).

[Table 1 about here] 
Sales digitalization represents an evolution of salesforce automation (SFA). In 1962, Richard Christian stated in a Journal of Marketing article that... "ten years from now... automation and electronics will affect practically everything we do" (p. 79). Indeed, by the 1980s, salesforce automation (SFA) had escalated its inroads in sales organizations. Defined as "...the application of information technology to support the sales function" (Buttle, Ang, and Iriana 2006, p. 214), SFA includes technological artifacts (hardware and software tools) designed to improve sales force productivity by automating processes, such as customer relationship management (CRM), repetitive and straight-buy sales, and other administrative tasks (Cascio, Mariadoss and Mouri 2010; Hunter and Perrault 2006). Existing research on SFA has focused primarily on its adoption, use, and impact on performance (see, for example, Honeycutt 2005; Jelinek 2013; Speier and Venkatesh 2002). Sales digitalization expands the role of technology by including digital assets such as digital marketplaces, IoT, AI, and digital products and services (Ross 2017). Digital assets can range from a mobile app to an online ordering site. Using an iPad and a customized app, for example, FMCG sales representatives can demonstrate the actual size of an in-aisle display to a supermarket manager, thereby increasing presentation effectiveness and the likelihood of a close.

Research conducted by the McKinsey Global Institute found that automation can be applied to $40 \%$ of the sales function; this number is expected to rise to $50 \%$ with high-tech developments such as AI (De Uster 2018). Many sales tasks considered impossible to computerize a few years ago, such as lead generation, can now be automated. AI capabilities include making recommendations that facilitate improvement in salesperson-customer relationships (Roe 2017). AI-based chat-bots can answer customer questions immediately and with accuracy (Melas 2018). In one study, $80 \%$ of sales teams using AI reported improvements 
in customer retention (Colon 2018). With AI projected to take on recurring as well as sophisticated tasks, the sales profession could change dramatically.

AI can transform sales processes and customer interactions in a wide variety of ways, virtually changing the way business is conducted. The ability of the technology to facilitate these transformations does not necessarily mean that it can be leveraged by sales professionals. To do so, salespeople will need to develop business competencies in addition to sales competencies (Dickie 2018). How can the sales profession help its members prepare for these business competencies? Will mechanisms to assist in the development of this base of business competencies be available to members of the profession, e.g., through certification processes?

AI also has the potential to revolutionize training within the sales profession. When incorporated into mobile apps, AI chat-bots facilitate on-the-go sales simulations that provide feedback to the sales representative on the effectiveness of the sales presentation. Enterpriselevel learning simulations can be used to teach the business competencies discussed earlier, as well as help representatives understand the process the customer goes through in making business decisions (Brodo 2018). How is the use of AI affecting sales training effectiveness? Is the bar for performance raised for the entire sales profession with the introduction of AI to the training regimen? Will the impact of AI on sales training be disruptive or gradual?

\section{Sales-as-a-Profession: Value Creation}

Sales digitalization including AI technologies is also triggering fundamental changes to the value creation function of the sales profession. Value is created for customers when they perceive the benefits they receive to exceed the costs they need to expend (e.g., Ulaga and Eggert 2006). Creating and conveying value for customers has been deemed the central mission for all of marketing (e.g., Kotler et al. 2012) as well as the sales profession (e.g., Grove et al. 2018; 
Rackham and De Vincentis 1999). Specifically, companies increasingly (1) digitize sales

channels to simplify selling and buying processes, (2) digitalize sales funnels through AIpowered decision-making, and (3) digitally transform offerings in a way that helps customers deploy products more effectively. We elaborate on these three areas next. Table 2 summarizes the research priorities and questions we develop below.

[Table 2 about here]

\section{Value Creation and Digitized Sales Channels}

Aiming to increase selling efficiency, reduce costs and increase customer value, B2B companies are increasingly digitizing sales channels, complementing their sales forces with channels that require online rather than personal interaction (Thaichon et al. 2018). For instance, several B2B companies are introducing self-service technologies for customers, such as online shops that allow browsing for items, placing orders, and tracking shipping. In a similar vein, in many B2B industries, vendor-independent online platforms where diverse suppliers compete for customers are emerging. The success of Alibaba.com, a B2B trading platform, supports the value creation potential of such platforms by fostering competition and reducing informational asymmetries (Alibaba 2018).

Interestingly, suppliers are also increasingly introducing vendor-independent platforms in their industries despite its cannibalization risk. As an example, the steel distributor Klöckner's recently launched a platform XOM Materials that is intended to become "the Amazon of steel trading" (Klöckner 2018). ${ }^{1}$ Finally, companies are also introducing fully automated selling and

\footnotetext{
${ }^{1}$ https://www.foundry-planet.com/equipment/detail-view/e-shops-marketplaces-trading-systems-the-future-ofmetal-trading-is-digital/?cHash=7baa247cc7d8fa66f799ec40ba8e0803;\%20https://www.technikeinkauf.de/news/maerkte-unternehmen/kloeckner-startup-xom-metals-das-amazon-des-stahlhandels/).
} 
purchasing, relieving customers of human effort. For example, C-parts supplier Würth Industries offers its customers systems based on scanners or RFID chips that automatically trigger (re)order placement when stocks fall below a certain filling level (Würth Industries 2018).

We know strikingly little about whether and how the emergence of digital sales channels transforms the sales profession's value creation function. The prognoses by practitioner literature widely differ: Some proclaim that digital sales channels will lead to the "Death of a (B2B) Salesman" (Forrester 2015), thus implying that the sales profession's value creation function will diminish the role of salespeople. Others believe the sales profession's focus on value creation will shift salespeople function from order-handling to consulting, particularly for complex products (e.g., Thull 2010). Future studies may explore how digital sales channels affect the sales profession both in terms of size and value creation tasks.

Digitization of sales channels may also provide novel opportunities for the sales profession to create value for customers and their own organizations. Specifically, by treating digital sales channels as a tool to serve customers, salespeople may create value through increased speed of service as well as time and cost savings. In our view, an intriguing research void in this respect refers to the question how salespeople do and should integrate digital sales channels in their selling efforts (e.g., Ahearne and Rapp 2010; Thaichon et al. 2018). For example, how can salespeople convey the value of digital sales channels to customers, particularly customers who are not digitally savvy? When and with what success do salespeople promote digital channels to customers (e.g., Ahearne and Rapp 2010)? How can companies foster salespeople's acceptance of digital sales channels as an opportunity for value creation? 


\section{Value Creation and Digitalized Sales Funnels}

$\mathrm{AI}$ engines that generate value for customers are widely prevalent in $\mathrm{B} 2 \mathrm{C}$ industries. Well-known examples include Amazon and Netflix that provide personalized product recommendations to fulfill customers' needs (Wedel and Kannan 2016). The field of B2B selling is witnessing a similar infusion of AI technologies all along the sales funnel. For instance, AI is used to identify and qualify leads that can benefit from a company's value proposition. Marketing automation tools such as Pardot, Hubspot, and Marketo track prospects' interaction with a company and "intelligently" nurture them until they are ready to be approached by a salesperson (Järvinen and Taiminen 2016). AI technologies are also increasingly used to analyze the needs of prospects to improve the sales profession's value creation. For example, solutions like JOYai determine a prospect's personality from social media footprint so that salespeople can then adapt the value proposition to individual preferences (JOYai 2018).

Similarly, based on a customer's purchase history, AI technologies are used to predict buyer's future need for products and services. ${ }^{2}$ In a similar vein, B2B companies are increasingly using AI technologies to improve how value is conveyed. Previously mentioned JOYai recommends specific messages salespeople may use based on a prospect's personality (JOYai 2018). Showpad guides salespeople through the argumentation that has proven to be successful in past interactions (Showpad 2018), while Mattersight matches customers to call center agents with similar personalities (Mattersight 2018). Lastly, a construction company we are familiar with uses AI-powered augmented reality goggles to give customers a realistic view of what a solution will look like.

\footnotetext{
${ }^{2}$ https://www.salesforce.com/solutions/industries/retail/resources/product-recommendation-engines/
} 
Also, B2B companies increasingly use AI technologies to help in sales negotiations and closing. Specifically, based on several customer characteristics such as industry, size, and prior relationship, AI algorithms compute a buyer's reservation price which can be a useful benchmark for salespeople. To strengthen customer relationships, B2B companies use AI technologies to predict a buyer's churn probability from recent purchase behaviors. Based on this guidance from AI, salespeople can then initiate retention measures. Furthermore, companies are increasingly using AI-powered chatbots to provide quick customer service.

We see three pressing issues that future research should address. First, we hold that academic research needs to examine the effectiveness of prevalent AI technologies empirically. That is, which AI technology is effective in enhancing the salesperson's value creation, for what kinds of buyers, and under what conditions? For example, do salespeople create higher value for buyers if they are equipped with intelligence from AI technologies? Are there segments of salespeople and buyers that benefit more from such insights (e.g., salespeople with low perspective taking, buyers with low skepticism)? In which contexts does salesperson's intuition (e.g., Hall, Sujan, and Ahearne 2015) outperform AI and vice versa?

Second, several questions need examination to understand how AI technologies may be integrated in the sales profession for fostering value creation. How can salespeople with algorithm aversion be motivated to use AI (Dietvorst, Simmons, and Massey 2016)? What capabilities do salespeople need to utilize AI effectively? How much leeway should managers afford salespeople to overrule an AI-based recommendation if experience or intuition suggests otherwise?

Third, we encourage research on the ethical implications of AI-based value creation and sales communication. To illustrate, the rise and fall of Cambridge Analytica have provided 
anecdotal evidence of pitfalls of "creating" value based on customization of advertisements to viewers' personality ${ }^{3}$. Future studies may build on the notion that AI may factually increase value generated by salespeople, but it may likewise be used to shift value away from customers to suppliers (e.g., AI-powered dynamic pricing) or create an illusion of value through targeted influence tactics (e.g., Cialdini 2001; McFarland, Challagalla, and Shervani 2006).

\section{Value Creation and Digitally Transformed Offerings}

Digitally transformed offerings typically provide customers with the information required to deploy a product effectively. At a conceptual level, this way of creating value is not new. As early as 1985, Porter and Millar noted that "[h]istorically, a product's physical component has been more important than its information component. The new technology, however, makes it feasible to supply far more information along with the physical product. For example, [...] some railroad and trucking companies offer up-to-the-minute information on the whereabouts of shippers' freight, which improves coordination between shippers and the railroad.” (p. 7). With the rise in digitally transformed offerings, companies are increasing the information component in the era of AI. Examples include predictive maintenance analytics of machine manufacturers (e.g., Wang et al. 2017) as well as precision farming technologies for the agricultural equipment industry (e.g., John Deere 2018).

For the sales profession's value creation function, digitally transformed offerings evoke substantial complexities. First, the technologies underlying such digitally transformed offerings are often beyond salespeople's expertise and rapidly evolving, rendering it difficult to understand and explain their value to customers (e.g., Ploetner 2016). Second, alongside digital offerings,

\footnotetext{
${ }^{3}$ https://www.theguardian.com/news/2018/mar/17/data-war-whistleblower-christopher-wylie-faceook-nix-bannontrump
} 
new revenue models are evolving, such usage-based pricing. An example is Rolls-Royce's wellknown "power by the hour", which entails selling jet engine power rather than the jet engine itself to airlines (Girotra and Netessine 2011). As a result, salespeople "still need to have knowledge of the technology of aircraft engines, but in addition they also need to understand modern information and communication technologies. Furthermore, they must have a working knowledge of business terms and concepts to be able to discuss what commercial impacts the new business model will have on the customer." (Ploetner 2016, p. 14).

Several avenues for research may significantly advance our understanding of digitally transformed offerings. First, it is useful to explore how the sales profession's value creation function is changing due to the introduction of digitally transformed offerings. Second, future research may conceptualize how the sales profession's value creation function should change when moving toward digitally transformed offerings. As a theoretical basis, we can envision that studies may draw on literature on value creation (e.g., Lindgreen et al. 2012; Payne, Frow, and Eggert 2017; Terho et al. 2012, 2015), servitization (e.g., Macdonald, Kleinaltenkamp, and Wilson 2016; Panagopoulos, Rapp, and Ogilvie 2017; Tuli, Kohli, and Bharadwaj 2007; Ulaga and Loveland 2014; Ulaga and Reinartz 2011), as well as the interface between sales and innovation (e.g., Ernst, Hoyer, and Rübsaamen 2010; Hohenberg and Homburg 2016; Homburg et al. 2017). Third, future research may examine how sales profession's value creation function is and should be evolving and provide guidance on how to manage the transition.

\section{Sales-as-a-Professional: Organizational Aspects}

Most salespeople, especially in the B2B domain, are expected to provide comprehensive customer solutions instead of selling individual products or services (Tuli, Kohli, and Bharadwaj 2007). Facilitated by digitalization, several solutions are co-created with customers, and at times, 
salespeople have to identify, and highlight needs that the customers did not even know existed. In the changing environment, companies are also dispersing their marketing capabilities, including sales, both within and across the organizations (Krush, Sohi, and Saini 2015). This has resulted in the blurring of the boundaries between traditional functional areas and the emergence of new sales models, such as "on-demand sales platforms" being used by companies such as Universal Avenue (www.universalavenue.com). Additionally, digital transformation has resulted in companies developing webs of alliances to manage the inter-organizational and intraorganizational dispersion of sales capabilities, and yet, develop and provide customer solutions effectively. Digitalization is also enabling companies to understand the marketplace better and provide more effective customer solutions.

These paradigm shifts are raising many questions about the changing nature of sales and the structure of sales organizations. Selling is no longer being viewed as a dyadic process between a buyer and a seller. Instead, scholars suggest that selling is a process in which a broader set of actors - on the buyer's and the seller's sides, as well as those who are a part of the broader market ecosystem - are engaged in creating and institutionalizing solutions. In other words, selling today "brings about alignment in the institutional arrangements of actors and therefore facilitates exchange and value co-creation among dynamic sets of actors" (Hartmann, Wieland, and Vargo 2018). The challenges faced by today's sales organizations are further compounded by the fact that today's buyers are more empowered, and demand complex combinations of products and services.

Further, given the institutionalization of the selling process, we are witnessing myriad ways in which competitors are disintermediating and re-intermediating value chains, thereby redefining the nature of value being created within business markets. While these 
transformations have indeed heralded painful changes for many in sales, innovative leaders are focusing on the digital transformation of their organizations and sales forces to compete in the changing environment. However, there is little guidance on how to organize and structure the sales force to operate successfully, and how to manage the organization across multiple, and often changing interfaces. These are critical areas for sales scholars to grapple with because the consequences of the organizational decisions have cascading effects on the knowledge, skills, and activities that salespeople need to be successful. We elaborate on these areas next. Table 3 summarizes the research priorities and questions that flow from our elaboration.

[Table 3 about here]

\section{Organizing and Structuring the Salesforce}

In general, there is little research focusing on sales force organization decisions (Albers and Mantrala 2008) perhaps owing to the complexity of the context. We begin to address this challenge here by drawing from previous conceptual frameworks to help understand and isolate potential connections between the environment and sales force structure decisions. We acknowledge that sales scholars have delineated environmental influences affecting organizational adaptations in the sales force. For example, building on the recognition that dynamism in the selling environment is ever present, Jones et al. (2005) provide a conceptual framework to identify the dimensions of change that are consistently influencing the sales force. To date, this conceptualization illustrates the most comprehensive perspective on the external (i.e., customer, competitor, technology, regulatory) as well as internal (i.e., new products, mergers and acquisitions, productivity) influences that have important implications for sales force level decision-making. In a related article, Zoltners, Sinha, and Lorimer (2008) create a sales force effectiveness framework that includes the drivers which define the salesforce 
structure. The authors carve out this component to be determined by decisions regarding sales force design, structure, roles, size, and territory alignment.

These articles point to potential connections between environmental changes and various structural decisions made at the sales force level. For example, what types of structures and roles have been introduced in response to increasing customer demands? How have changes in technology influenced decisions over sales force design? Shifting to an internal perspective as another way to establish new research avenues, how do shifts in company strategy, shaped by digital transformation, impact sales force structures? We highlight a selection of sales research that has begun to examine these contexts.

Research has begun to identify significant shifts in the structural design of the sales force to meet the needs of increasingly demanding customers and dynamic technological advancements. One major shift is the use of inside sales roles within the sales force. The growth of inside sales is driven by several factors such as technological innovation, increasing customer demands, and a greater emphasis on cost control (Rapp et al. 2012). Many organizations have relied on this growth to complement their outside sales force and online channels to create hybrid sales structures. As a relatively new form of sales force design, hybrid sales structures heavily rely on coordination between inside sales, outside sales, and online channels to deliver value along the various points in the customer purchase process (Thaichon et al. 2018).

Another significant change that is impacting selling today is the tighter integration of technology within the sales processes (Thaichon et al. 2018). The ever-increasing use of technologies and tools such as artificial intelligence, online content, as well as a variety of digital channels and other technological platforms are making it possible for business organizations to not only customize their value propositions but also enhance buyers' experience during the sales 
process. The extensive integration of technology is also helping companies make buying processes simpler, as well as redefine and maximize customer value (e.g., through offering virtual experiences of products or services, or using multi-sensory selling techniques).

The exploding number of technological tools and processes that are now a regular part of many salespeople's routines are impactful on sales force structure as well. A new functional part of the sales force called sales enablement has emerged to manage this domain. Sales enablement groups are being established in many firms with a focus on providing salespeople with technology and information to sell more efficiently. These sales enablement roles are primarily responsible for drawing insights from sales activity data and creating digital content for sales leaders and salespeople to improve performance.

Other related trends point to the changing nature of the sales force. For example, many firms are opting for more specialized role structures to align customers' buying expectations, as well as multiple customer roles with matching sales capabilities (Bradford et al. 2010). These structures have typically diminished the number of generalist field salespeople and replaced them with a team of specialized roles. These multi-specialization sales teams have become commonplace, often comprised of multiple functions such as a sales development representative, account manager, technical salesperson, or customer success manager. Some other sales organizations are adopting a different structure with the use of ambidextrous sales organizations. Here, firms are responding to rising sales targets, cost pressures, and customers' demands for fewer supplier touchpoints by combining various customer-facing responsibilities into one role. For example, many sales leaders are calling upon salespeople to deliver occasionally conflicting roles such as sales and service (Rapp et al. 2017), or similarly, hunting and farming (DeCarlo and Lam 2016), to capitalize on the potential to create customer value while being more cost- 
efficient. Thus, there are a number of possible new ways to organize and structure sales roles for cooperation, efficiency, customer support, and ultimately sales performance.

\section{Future Directions}

Despite these significant shifts in sales force roles and structures, research has been slow to transition away from the more traditional, homogeneous sales force conceptualizations. However, this dearth of research presents what may be the sales research area with the most opportunity. We propose multiple lines of inquiry for future researchers to help understand the implications of changing sales force structures.

The increasing use of insides sales roles has been relatively overlooked in sales research. The rise of inside roles has long been anecdotally driven by cost-conscious growth, but it remains unclear whether increasing the size or proportion of inside sales is optimal for sales performance outcomes. With the exception of (Rapp et al. 2012) who find contingent effects of sales force structural decisions on customer orientation and inter-functional coordination, we have little understanding of the impact of sales force structure on outcomes. Future research can begin to examine how the shifting makeup of the sales force influences sales performance across many other dimensions. It is also important for research in this domain to answer the call for more macro level research (Cron 2017). Salesforce decisions are influential to many stakeholders beyond individual customers and salespeople, such as other firm functions (e.g., marketing, operations), sales managers, and investors. For example, recent research by Panagopoulos, Mullins, and Avramidis (2018), links sales force sizing decisions to stock market performance. Their use of theory on market-based assets (Srivastava, Shervani, and Fahey 1998) to conceptualize the sales force as a driver of cash flow volatility sets the stage for future research to understand how sales force structure changes impact firm-level outcomes. Understanding 
when and how to implement a specialized versus generalist sales force structure is another area ripe for investigation.

Digital transformation has spawned multiple changes worth noting. First, hybrid sales organizations, which utilize digital channels alongside inside and outside salespeople, are becoming more prevalent. While theoretical frameworks have been proposed (e.g., social exchange theory, network theory, value creation) to understand hybrid sales organizations (see Thaichon et al. 2018), this new sales organization poses many new challenges that have yet to be studied. For example, by its nature, hybrid sales organizations will generate multiple touchpoints and value exchanges between members of the sales organization and customers. These touchpoints will vary by medium (e.g., social media, phone call, virtual, and in-person), as well as by salesperson. Given all this variation, how do sales organizations organize the sales process and sales roles to benefit the customer most? This line of inquiry brings up a second new change in sales organizations - the creation of sales enablement roles. Like the challenges in hybrid sales organizations, sales enablement roles introduce another touchpoint in the sales process, except here the resource exchange is internal (i.e., between enablement roles and salesperson roles). What value is captured or lost when adding this new type of sales organization?

The last major area of inquiry centers around decisions to create specialized versus generalized sales roles in the sales organization. While specialized sales roles may be able to deliver more customized knowledge and customer intelligence, it may be less efficient for the organization. On the other hand, generalized sales roles may be too taxing for the salespeople to handle all the tasks, activities, KPIs, and knowledge required for the role. Research on ambidextrous roles have begun to tackle some of these questions (DeCarlo and Lam 2016; Jasmand, Blazevic, and de Ruyter 2012), but many knowledge gaps remain. Relatedly, the use of 
specialized sales roles increases the emphasis on team selling, yet research addressing the coordinated use of these roles is scarce (see Mullins and Panagopoulos 2018). Future research could begin to draw from team frameworks (Marks, Mathieu, and Zaccaro 2001; Mathieu et al. 2008) to understand how sizing, composition, KPIs, management, processes, and skills influence success in team selling environments.

\section{Sales Interfaces}

The scholarly investigation into sales function's intra-organizational interfaces has mostly centered on the sales-marketing interface - that is, how sales and marketing functions within an organization interact with one another. Primarily, this is because in many B2B organizations, sales and marketing have a joint responsibility to create and deliver superior customer value (Homburg and Jensen 2007; Malshe and Sohi 2009a; Malshe and Sohi 2009b). While it is imperative that sales and marketing functions work optimally and play nice with one another in the best interest of the firm's overall value creation activities, evidence from the past 30 years' worth of scholarship suggests that it is not the case in many organizations. The dynamic between sales and marketing in many firms is plagued by issues such as lack of adequate two-way communication, overt and covert conflicts, lack of integration, collaboration, and coordination, as well as lack of trust and mutual credibility between sales and marketing, to name a few (Rouziès et al. 2005). Overall, the dysfunctional nature of this interface in many organizations hampers the firm's ability to convert sales leads into actual business and results in a drain on company resources in the form of wasted marketing dollars as well as lost revenue (Malshe, Johnson, and Viio 2017).

While organizations are still trying to navigate the treacherous sales-marketing interface waters, working tirelessly to identify better ways to make the sales-marketing interfaces more 
harmonious and consequently productive, changes in the external environment are complicating matters. Specifically, they are forcing organizations to widen their horizons and think beyond the traditional sales-marketing interface as a contributor to the value creation process.

\section{Future Directions}

With digital transformation and multiple actors becoming intricately involved in the sales process, investigation of sales interfaces will require scholars to look beyond how the sales function interacts with their marketing counterparts in their value creation endeavors. Going forward, scholars will need to examine the sales function's interfaces with a variety of different entities, both within and external to the organization, that are involved directly or indirectly in the selling process. Tomorrow's selling processes are likely to be collaborative endeavors wherein sales personnel are likely to work hand in hand with multiple ecosystem partners to orchestrate complex sales solutions. Further, sales personnel are more and more likely to orchestrate activities of a set of internal and external players within the institutional settings during the sales processes. In such situations, sales personnel are likely to become a critical central node within the network of internal and external players that constitute the selling ecosystem. Further, there may be selling situations wherein at certain stages during a long, complex sales process, sales personnel may play a supporting role to other intra-organizational entities that are extensively engaged in the sales process during that stage.

Salespeople have always played a crucial role in gathering market information and developing competitive intelligence. However, most of the intelligence is in the form of local knowledge that resides with the salesperson. With evolving interfaces and the role that salespeople might occupy within a network of internal and external players, it would be crucial 
for companies to leverage this local knowledge by converting it to collective intelligence at the organizational and network level.

For this to happen, communication patterns between the sales organization and other intra and extra-organizational entities that support them in the value creation and delivery process in the marketplace would need to undergo metamorphosis (Deepa and Deshmukh 2013; Michaelidou, Siamagka, and Christodoulides 2011). At a minimum, sales and their supporting organizations will need to think actively about ways that will allow them to develop and leverage their respective knowledge stores. There are several issues related to this that open avenues for further research. Some of these include, training salespeople to gather intelligence that is useful for the organization, developing organizational capabilities to leverage knowledge that may be situated in multiple inter-and intra-organizational entities, using artificial intelligence to build market sensing capabilities and to convert local intelligence to collective intelligence, and perhaps, using social media and other technologies to crowd-source intelligence gathering.

\section{Sales-as-a-Professional: Individual Aspects}

As developments in digital technologies challenge our current understanding of how sales organizations operate, it will also affect the role of the salesperson, which raises the question how will individual salespeople operate and succeed in this new age? We extend the discussion of how sales organizations' value creation activities are shifting, because of digitization and AI, to consider the changing role of the individual salesperson. We provide a brief overview of relevant research and offer new research priorities surrounding three general areas, including 1) transformed individual sales roles and activities, 2) expected salesperson knowledge, skills, and abilities, and finally, 3) the impact of digital technologies on the salesperson. Table 4 summarizes the research priorities and questions that flow from our discussion below. 
[Table 4 about here]

\section{Individual Salesperson Roles and Activities}

Given significant developments in digitization and AI, it is important to consider the changing landscape of sales roles and activities. Again, these advancements have led to potential new opportunities (or threats) for sales organizations to manage. As sales companies scramble to capitalize on opportunities resulting from the emergence of new digital channels, we can predict that the sales tasks and activities required of salespeople are changing in tandem. Earlier, we posed the question of how new digital sales channels will transform the sales value creation function? Relatedly, we now consider how a company's introduction of a digital sales channel will affect salesperson activities. What changes in the sales process and associated salesperson activities can we expect?

Past research provides various classification schemes that capture the scope of sales activities. In 1986, Moncrief provided an initial descriptive taxonomy of sales positions based on patterns of sales activities across various sales jobs. Recognizing that the sales job had changed over time, due to new technologies and rising customer expectations, Moncrief, Marshall, and Lassk offered an updated taxonomy in 2006. This 2006 taxonomy provides the most recent attempt to categorize sales jobs according to a comprehensive consideration of individual-level salesperson activities. In short, the taxonomy proposed six types of sales jobs that emphasized various sales activities. For instance, the 'consultative seller' focuses predominantly on relationship selling and providing promotion and service support. The 'new business seller' relies more on technology, and spends more time entertaining, prospecting, and training. The 'missionary seller' is engaged in training, travel, and delivering the product, but does not engage in prospecting. The 'delivery seller' focuses primarily on delivering and stocking product, and 
sometimes on prospecting. The 'sales support' position focuses more on office tasks, training and recruiting. Finally, the 'key account seller' engages in product support activities, travel, and office support activities. The taxonomy served two purposes. First, it provided a comprehensive investigation of the actual work, or activities, that salespeople perform. Second, it supported the idea that different types of sales jobs or positions exist.

Researchers built on this premise to consider the nature of various sales activities and their effect on sales performance. Johnson and Selnes (2004) and Gupta and Zeithaml (2006) suggest that the sales activities required for customer acquisition versus customer retention differ. Carter et al. (2014) show that the amount of time that salespeople choose to allocate to customer acquisition efforts versus retention affects performance. Also, DeCarlo and Lam (2016) explain when and why salespeople develop preferences for acquisition versus retention types of sales activities, and how the sales organization can manage these preferences to arrive at the best sales outcomes. They suggest that there are trade-offs between customer acquisition (i.e., hunting) and retention (i.e., farming) activities, and there is a need to balance both (i.e., ambidexterity). Their framework also provides some clarity regarding the antecedent conditions that lead to salesperson preferences for hunting versus farming. Sleep, Bharadwaj, and Lam (2015) explore how salesperson activities impact consequences, including customer satisfaction and performance.

Other related research has identified and advocated for the addition of newly identified salesperson activities and other suggested changes to the sales process. For instance, Andzulis, Panagopoulos, and Rapp (2012) suggest ways in which social media has resulted in changes to the sales process. They identify new activities that are likely to occur at each stage of the sales process, because of the use of social media. Rapp et al. (2015) identify another specific new 
activity for salespeople involving the collection and use of competitive intelligence. As a final example, Hunter and Perreault (2007) introduce additional relationship-forging tasks as key activities salespeople ought to engage in. Their research suggests that these tasks, including sharing market knowledge and proposing integrative solutions, are particularly important in determining the impact of sales technology on effective relationship building in sales.

\section{Future Directions}

While this research has provided a solid foundation to consider sales activities and processes in the past, new learning resulting from digitization and developments related to AI are enabling potential changes in salesperson activities. Digital technologies now support the automation of many traditional sales roles (Syam and Sharma 2018). If companies effectively leverage digitization and AI capabilities, they will be able to automate aspects of the sales process beginning with customer acquisition and extending through customer retention. Organizations can shift some of these functions to online platforms.

Considering these changes, it is evident that it is time for a new and comprehensive investigation of the sales process and activities. A recent taxonomy (Moncrief, Marshall, and Lassk, 2006) details a wide range of activities, such as building rapport, asking questions, entertaining, searching out new leads to learning software. To what extent does this list accurately reflect the range of salespeople's activities today? With digitization and AI, have certain activities (e.g., generating leads, training salespeople) diminished? Also, to what extent do salespeople participate in 'new' activities that were not identified, or did not exist, in the 2006 study? How much time and effort do salespeople direct to interfacing with other touchpoints within the company? The time is ripe to provide a new taxonomy and reconsider antecedents and consequences associated with sales performance along these activities. 
Digital technologies have also impacted the customer exchange experience. Today's customers have access to a wealth of information, including the product's and service's technical benefits and deficiencies, as well as peer reviews. They also have many opportunities to be active contributors to information generation and exchange with their peers. This has given way to a more informed and collaborative role for the customer. As the customer role has evolved, there is a need to consider how these changes will influence the role of the salesperson.

Scholars have begun to evaluate how the changing role of the customer has affected marketing, more generally. Both academics and practitioners agree that Customer Experience Management is crucial. Customer Experience Management is conceptualized as a higher-order construct encompassing certain cultural mindsets, strategic directions, and firm capabilities that are focused on managing every touchpoint across the scope of the customer journey (e.g., Homburg, Jozic, and Kuehnl 2017). Customer Experience Management calls for activities that serve to integrate touchpoints along a brand theme and ensure a seamless transition across online and offline touchpoints. Customer relationship management involves a focus on the touchpoint journey that spans customer pre-purchase, purchase, and post-purchase phases (Homburg, Jozic, and Kuehnl 2017). There is a need to align different touchpoints along the journey, to produce desired results. The call for Customer Experience Management sheds light on new activities that are essential to developing customer loyalty and long-term sales results, many of which will involve the salesperson. Thus, it points to a new role for the salesperson—one that involves a greater focus on aligning, integrating, and consistently communicating brand information internally and externally.

Customer Engagement Marketing provides another fruitful avenue to consider. This framework suggests also acknowledges that customers are now active and influential participants 
in marketing efforts (Harmeling et al. 2016; Kozinets et al. 2010). If they so choose, customers can play an active role in customer acquisition, retention, information exchange, and sourcing new ideas for product innovation (Malthouse et al. 2013). Thus, firms ought to seek ways to manage or guide instances of customer engagement to benefit the firm's marketing strategy. As firms recognize the need to guide customer engagement attempts proactively, this brings up questions regarding the role that salespeople can play in influencing or managing the process. From their position on the frontlines, what actions will salespeople be asked to take on to inspire customers to voluntarily contribute to various aspects of the marketing function on behalf of the company? These modern marketing frameworks provide an updated perspective on the exchange that takes important changes in technology and customer roles into consideration. Using these ideas, we can begin to reconsider the emerging sales role.

\section{Knowledge, Skills, and Abilities (KSA)}

As companies seek to leverage digitization and AI, questions about the impact on salesperson's knowledge, skills and abilities have been raised. Sales technology generally has resulted in greater efficiency, providing tools that lead to faster processes and better market and customer knowledge stores (e.g., Ahearne, Jones, Rapp and Mathieu 2008). Digitization and AI have the potential to provide some real benefits to salespeople as they can free the salesperson from some of the more mundane aspects of the sales role, such as processing orders, and coding and transmitting customer and market information, so that they can concentrate on deeper customer interactions (Baker and Delpechitre 2013). In the following section, we consider the impact of these developments on salespeople's KSAs.

Knowledge is a crucial part of the salespeople's skill set. Both collective (sales team) and local knowledge are relevant to developing new sales leads and nurturing existing customer 
relationships. Digital technologies offer the potential to disrupt knowledge management processes, as machine learning can harness the information held in large datasets to provide strategic insights into customer behaviors and desires (Syam and Sharma 2018). It is possible that, through the integration of CRM systems into knowledge systems, that salespeople's local knowledge can now be integrated with the organizations so that the tacit knowledge previously only held in sales becomes more generalizable. Therefore, this explicit knowledge is more transferable within the organization and can be shared across functions more easily. Explicit sales knowledge can also help sales managers with accurate forecasting, cross-selling and lead scoring so that the performance of the sales team can be monitored, and skills can be enhanced (Antonio 2018).

Regarding new customer acquisition, digitization enables organizations to identify better prospects that are likely to respond positively. By identifying behavioral and buying patterns, digital technologies can serve to identify leads as well as provide intelligence on the decision points in the negotiation process (Hurley 2017; Syam and Sharma 2018). As companies begin to automate these processes, how is salesperson knowledge impacted? The main concern is that their interpersonal competencies are no longer required or valued. The salesperson's knowledge may become embedded in the systems of the organization and the customer, rather than being an independent conduit of tacit knowledge with the ability to build customer relationships (Ahearne et al. 2012). This could lead to salespeople losing their deep customer knowledge, unless new knowledge can be created by building interpersonal trust with the customer (Le MeunierFitzHugh and Douglas 2016).

Skills of the salesperson may also shift from a series of hard selling skills (selling and prospecting) to soft skills such as relationship building and emotional connectivity. Finding new 
ways of engaging with customers and satisfying their needs through innovative solutions, including leveraging digitization, are likely to lead to sales success (Leigh, De Carlo, Allbright and Lollar 2014). Digitization, in and of itself, cannot replace traditional sales methods, but instead offers the potential to embrace new learning and opportunities (Preston 2010). The challenge is not just to automate existing processes but also to reinvent the entire interactive process and develop automated decision making for sales. As this process unfolds, it is important to explore what skillset salespeople need to enable the process. Furthermore, the nature of these changing requirements of sales skills is dependent on the type of sale being undertaken, with the simple sale likely to be completely carried out automatically but more complex solution selling still relying on soft skills and negotiation abilities of a salesperson, supported by information gained through digital technology. Of course, the complex sales situation (often involving multiple large accounts) will require salespeople to become 'knowledge brokers' who can integrate intellectual capital from digitization with their own specific knowledge during the sale, and which could generate the need for a new set of interactive selling skills.

Many customers in the future are likely to be digital natives (Generation Y and Z), which will drive the need for greater digital content and multi-point interactions with the salesperson. Therefore, selling organizations who are early adopters of sales technology and AI will have the potential to lead the development of new sales skills based on social media interactions and deeper customer understanding (Syam and Sharma 2018). Despite reservations on the effects of digital technologies, the early evidence is that companies that effectively use these tools can retain their existing customers and acquire customers more efficiently (Loring 2018).

Sales Ability may be affected by digital technologies as it is an enabler and enhancer. Authenticity is critical in personal interactions as more businesses expect greater visibility in 
their interactions with salespeople (Hurley 2017). For example, as described earlier, AI can be used to provide activity-based, success roadmaps with early warning alerts about the progress of negotiations and the general health of customer relationships in an effort to trigger proper salesperson responses. However, whether automated responses can generate authenticity and deliver on this promise is not yet clear. Furthermore, it is not clear how the effectiveness of AI assistance can be measured.

There is some debate regarding the effect digital technologies will have on the salesperson's ability to extract customer insights and knowledge. Some suggest that customer insights developed through trust and emotional connectivity in interpersonal interactions between the salesperson and the customer may be lost if there is a greater reliance on automated processes. Alternatively, customer insights could be enhanced as the salesperson is relieved of the repetitive administrative tasks and can focus on relationship building elements (Loring 2018). Also, digital technologies may enable the salesperson to become more 'connected' to other organizational functions (Limbu, Jayachandran and Babin 2014), allowing for more seamless interaction and better touchpoint management. Additionally, companies can now use digital technologies to develop a set of behavioral analytics that could be used to coach salespeople to offer effective solutions at various points of the sales interaction (Hurley 2017). These different forms of connectivity and analysis offer opportunities for the salesperson to develop greater adaptability in their customer interactions, strategically adjusting the value proposition to align with customers' changing needs (Virtanen, Parvinen and Rollins 2015) and to build authentic relationships with their buyers. However, the benefits of new sales technologies will be reliant on the development of algorithms that adapt to the changing nature of the market, while still allowing the salesperson to be creative and innovative in their interactions. 
Performance could be affected by sales technologies as processing errors are reduced, the efficiency of action is increased, and value creation is enhanced. A benefit of employing sales technology and AI is the ability of the systems to manage salespeople's time more effectively, which increases productivity. The system would be able to pre-book meetings and organize salespeople's meeting and travel times more effectively (Hurley 2017). Salespeople may also stay longer in the job as there is less stress, role conflict, and ambiguity as technology generates standardization. Digital technologies should provide ways to collect knowledge that can be analyzed to form intellectual capital and facilitate the dissemination of information that builds competitive advantage. Creating a positive feedback loop between the organization and the salesperson allows this intellectual capital to be integrated with specific product and customer knowledge to improve their performance (Mariadoss, Milewicz, Lee and Sahaym 2014).

Technology continues to drive improvements in crossover in the roles played by sales and marketing people, which result in increased output and better value propositions. Due to the introduction of new digital channels, the roles of sales and marketing are becoming more intertwined and boundaries removed. The creation of Blogs or other net chatter means that marketing people are becoming sellers and salespeople are becoming online marketers, increasing the necessity for sales and marketing to collaborate and to develop new sales/marketing skills (Le Meunier-FitzHugh and Douglas 2016). Salespeople will also need training in the use of social media to engage with customers, as well as establish themselves through digital media as 'experts' in their field, to fulfill their potential when developing customer relationships in the new connected world. This debate highlights several gaps in our understanding of salesperson KSAs and points to emerging research priorities. 


\section{Implementing Digital Technologies and Salesperson Responses}

Lastly, we explore salesperson reactions to digital technologies and its potential impact on effective implementation. In particular, we focus on two areas, including 1) salesperson reactions to codifying personal knowledge stores, and 2) salesperson likelihood to adopt, and otherwise respond positively, to the implementation of new digital technologies.

Practically speaking, the use of AI requires that an expert transform tacit heuristics into a codified set of decision rules. These rules then provide the structure for applying new learning gained from digitization. The user of AI only needs to enter the main parameters indicated by the expert. The AI then applies the decision rules to generate analysis, insights, and ultimately, a recommendation. Thus, in many respects, AI represents a conscious attempt to codify tacit knowledge to make it available to and/or imitable by "others" (Coff, Coff, and Eastvold 2006; Gill, 1996; Lado and Zhang 1998; Mata, Fuerst, and Barney 1995). The expert could be a star salesperson and/or an experienced salesperson. "Others" could be average and below average salespeople, or less experienced salespeople, within or outside the focal organization. Thus, it is conceivable that due to the codification and transfer of expert knowledge, digital technologies could diminish the advantage hitherto enjoyed by the salesperson expert both in current and future firms, which could also undermine their ability to command higher pay.

This raises an important question: is it possible to use AI and other digitized platforms so that an individual salesperson can leverage his or her tacit knowledge without codifying and transferring such knowledge? Some AI might not require much codification. For example, AI built for predictable and routine tasks can be programmed with explicit and general knowledge. Such AI will not be as threatening to the expert salesperson. Given that resistance to change constitutes the most significant obstacle during new technology implementation (Heracleous and 
Barrett 2001), cooperation and motivation are important in facilitating the knowledge transfer process (Osterloh and Frey 2000). Hence, expert systems (e.g., AI) that require less codification might facilitate implementation, considerably (Coff, Coff, and Eastvold 2006). Future research should explore how characteristics of the AI system ultimately influence salesperson attitudes and behaviors in response to the implementation of the system. For example, how does the amount, and complexity, of codification required for the AI system in question influence the gains expected for the individual versus the organization? It is likely that the gains achieved through the application of AI, are not always equally split among the individual and the organization. To the extent that the benefit of implementing AI is idiosyncratic to the organization, it may reduce external demand for the salesperson. As a result, the salesperson may lose bargaining power. As technology-leveraged experts increase the organization-specific component of their knowledge over time, they lose power (Coff, Coff, and Eastvold 2006). How will this power shift impact the salesperson's compensation and value to the organization? Moreover, will salesperson reactions to AI vary depending on the level of codification and transfer required for $\mathrm{AI}$ implementation?

Another relevant salesperson response to implementation of digital technologies concerns adoption. To what extent will individuals embrace digitization and application of $\mathrm{AI}$ in the workplace? We suggest that the salesperson's "general robotic orientation" (Chao and Kozlowski 1986) may account for their response to new digital technologies such as AI. Is it still the case that salespeople are hesitant to adopt new technology? Are millennials and Generation $\mathrm{Z}$ more disposed to working with digital technologies? What steps can managers take to impact salesperson perceptions about $\mathrm{AI}$ and digitization in the workplace? There is an opportunity to leverage technology-related studies and measures developed in other disciplines, including past 
studies measuring "general robotic orientation" in applied psychology (Chao and Kozlowski 1986) to explain salesperson digital technology adoption and response. Ultimately, salesperson response is crucial. As salespeople become comfortable with these technologies, they will increasingly depend on them, and eventually, may be unable to function without them. If this occurs, then these digital technologies could lead to higher retention of salespeople because they will be less able to leverage their idiosyncratic knowledge, skills and abilities elsewhere.

Sales scholars should also explore how the nature of AI usage might affect individuallevel outcomes, including stress, motivation, and retention. The implementation of AI often results in changes in jobs due to the redistribution of tasks between humans and robots (Edwards 1984). Future research considering the reallocation of sales tasks (i.e., which tasks are automated) and its impact on the salesperson's stress, motivation, and performance are warranted. It may be possible to leverage prior work in technology to begin to address these questions. For instance, Parsons and Kearsley (1982) suggested nine activity foci to organize the division of labor between humans and robots. These activity foci include Surveillance, Intervention, Maintenance, Backup, Input, Output, Supervision, Inspection, and Synergy (SIMBIOSIS). This framework provides one example of how tasks can be categorized, which would then enable us to explore how salesperson responses to automating activities may vary depending on the type of activity. Specific research priorities surrounding these ideas are also presented in Table 4.

\section{Conclusion}

Building from a collaborative, bottom-up process of workshopping, this paper has aimed to develop the concepts, priorities, and questions to help guide future research in an age of sales digitization and artificial intelligence technologies. In so doing, we contribute to the field of 
personal selling and sales management by advancing the literature on sales force automation and frontline sales technologies (Buttle et al. 2006; Casico et al. 2010; Hunter and Perreault 2006). Our analyses reveal that the influence of sales digitalization technologies, which includes digitization and artificial intelligence, is likely to be more significant and more far-reaching than previous sales technologies. To capture this scope and breadth of influence, we have organized our development into three broad areas: (a) sales-as-a-profession and its value creation function, (b) sales-as-a-professional and its organizational function, and (c) sales-as-a-professional and its individual level function. In each area, we outline research priorities and questions that warrant consideration by researchers and practitioners alike. We hope our roadmap provides both the motivation and direction for future research that helps harness the power of sales digitalization technologies to lift and enhance the functioning of the sales profession and sales professional by the roles they perform and contributions they make to organizations, individuals and society. 


\section{References}

Albers, Sönke and Murali Mantrala. 2008. "Models for Sales Management Decisions," in Handbook of Marketing Decision Models: Springer.

Andzulis, James “Mick”, Nikolaos G. Panagopoulos, and Adam Rapp. 2012. "A Review of Social Media and Implications for the Sales Process." Journal of Personal Selling and Sales Management 32 (3): 305-16.

Ahearne, Michael, Eli Jones, Adam Rapp, and John Mathieu. 2008. "High Touch Through HighTech: The Impact of Salesperson Technology Usage on Sales Performance via Mediating Mechanisms." Management Science 54 (4): 671-686.

Ahearne, Michael, Douglas E. Hughes and Niels Schillewaert. 2007. "Why Sales Reps Should Welcome Information Technology: Measuring the Impact of CRM-Based IT on Sales Effectiveness." International Journal of Research in Marketing 24 (4): 336-349.

Ahearne, Michael and Adam Rapp. 2010. "The Role of Technology at the Interface between Salespeople and Consumers." The Journal of Personal Selling \& Sales Management 30 (2): 111-120.

Antonio, Victor. 2018. How AI Is Changing Sales, https://hbr.org/2018/07/how-ai-is-changing sales, Accessed on October 01, 2018.

Baker, David S. and Duleep Delpechitre. 2013. "Collectivistic and Individualistic Performance Expectancy in Utilization of Sales Automation Technology in an International Field Sales Setting." Journal of Personal Selling \& Sales Management 33 (3): 277-88.

Baumgartner, T., Hatami, H. \& Valdivieso, M. 2016. The new world of sales growth. McKinsey \& Company, Available at: https://www.mckinsey.com/business-functions/marketing-andsales/our-insights/the-new-world-of-sales-growth, Accessed on 11/09/2018.

Bradford, Kevin, Steven Brown, Shankar Ganesan, Gary Hunter, Vincent Onyemah, Robert Palmatier, Dominique Rouziès, Rosann Spiro, Harish Sujan, and Barton Weitz. 2010. "The Embedded Sales Force: Connecting Buying and Selling Organizations." Marketing Letters 21 (3): 239-53.

Brennan, Scott and Daniel Kreiss. 2014. "Digitalization and Digitization." Culture Digitally September 8. http://culturedigitally.org/2014/09/digitalization-and-digitization/, Accessed on $10 / 18 / 2018$.

Brodo, Robert. 2018. "For Sales Professionals, Practice Makes Perfect." Talent Development 72 (5): 44-48.

Buttle, Francis, Lawrence Ang and Reiny Iriana. 2006. "Sales Force Automation: Review, Critique, Research Agenda.” International Journal of Management Reviews 8 (4): 213231. 
Carter, Robert E., Connor M. Henderson, and Robert W. Palmatier. 2014. "Effect of Salespeople's Acquisition-retention Trade-off on Performance." Journal of Personal Selling and Sales Management 34 (2): 91-103.

Cascio, Wayne F. and Ramiro Montealegre. 2016. "How Technology is Changing Work and Organizations." Annual Review of Organizational Psychology and Organizational Behavior 3: 349-375.

Cascio, Robert, Babu John Mariadoss and Nacef Mouri. 2010. "The Impact of Management Commitment Alignment on Salespersons' Adoption of Salesforce Automation Technologies: An Empirical Investigation.” Industrial Marketing Management 39 (7): 1088-1096.

Chao, Georgia T. and Steve W. J. Kozlowski. 1986. "Employee Perception on the Implementation of Robotic Manufacturing Technology." Journal of Applied Psychology 71 (1): 70-76.

Christian, Richard C. 1962. "The Computer and the Marketing Man.” Journal of Marketing 26 (4): 79-82.

Cialdini, Robert B. 2001. "Harnessing the Science of Persuasion." Harvard Business Review 79 (9): 72-81.

Coff, Russell W. 1999. “When Competitive Advantage Doesn't Lead to Performance: The Resource-based View and Stakeholder Bargaining Power." Organization Science 10 (2): 119-133.

Coff, Russell W., David C. Coff., and Roger Eastvold. 2006. "The Knowledge-Leveraging Paradox: How to Achieve Scale without Making Knowledge Imitable." Academy of Management Review 31 (2): 452-465.

Collins, Robert H. 1984. "Artificial Intelligence in Personal Selling.” Journal of Personal Selling \& Sales Management 4 (1): 58-66.

Colon, Tony 2018. "Eight Tips for Boosting Sales in Your Digital Sales Transformation," Forbes, July 13, 2018, https://www.forbes.com/sites/forbestechcouncil/2018/07/13/eighttips-for-boosting-sales-in-your-digital-sales-transformation/\#1a55fe3f52a0, Accessed $11 / 09 / 2018$

Cron, William L. 2017. "Macro Sales Force Research." Journal of Personal Selling \& Sales Management 37 (3): 188-97.

DeCarlo, Thomas E. and Son K. Lam. 2016. "Identifying Effective Hunters and Farmers in the Salesforce: A Dispositional-situational Framework." Journal of the Academy of Marketing Science 44 (4): 415-439. 
De Uster, Maria Valdivieso De Uster. 2018. "The 7 Biggest Trends Upending Sales Today." Available at https://www.salesforce.com/quotable/articles/biggest-sales-trends/, Accessed on 10/2/2018.

Deepa, N. and Sagar Deshmukh. 2013. "Social Media Marketing: The Next Generation of Business Engagement." International Journal of Management Research and Reviews 3 (2): 2461-68.

Dickie, Jim. 2018. “3 Things to Keep in Mind as AI Comes to Sales.” CRM Magazine 22 (2): 4.

Dietvorst, Berkeley J., Joseph P. Simmons, and Cade Massey. 2016. "Overcoming Algorithm Aversion: People Will Use Imperfect Algorithms if They Can (Even Slightly) Modify Them." Management Science 64 (3): 1155-1170.

Edwards, Mary. 1984. "Robots in Industry: An Overview." Applied Ergonomics 15 (1): 45-53.

Ernst, Holger, Wayne D. Hoyer, and Carsten Rübsaamen. 2010. "Sales, Marketing, and Research-and-Development Cooperation across New Product Development Stages: Implications for Success.” Journal of Marketing 74 (5): 80-92.

Gill, Grandon T. 1996. "Expert Systems Usage: Task Change and Intrinsic Motivation." MIS Quarterly 20 (3): 301-329.

Girotra, Karan and Serguei Netessine. 2011. "How to Build Risk into Your Business Model." Harvard Business Review 89 (5): 100-105.

Grove, Hannah, Kevin Sellers, Richard Ettenson, and Jonathan Knowles. 2018. "Selling Solutions Isn't Enough.” MIT Sloan Management Review 60 (1): 55-59.

Gupta, Sunil and Valerie Zeithaml. 2006. "Customer Metrics and Their Impact on Financial Performance.” Marketing Science 25 (6): 718-739.

Hall, Zachary R., Michael Ahearne, and Harish Sujan. 2015. "The Importance of Starting Right: The Influence of Accurate Intuition On Performance in Salesperson - Customer Interactions." Journal of Marketing 79 (3): 91-109.

Harmeling, Colleen M., Jordan W. Moffett, Mark J. Arnold, and Brad D. Carlson. 2016. "Toward a Theory of Customer Engagement Marketing." Journal of the Academy of Marketing Science 45 (3): 312-335.

Hartmann, Nathaniel N., Heiko Wieland, and Stephen L. Vargo. 2018. "Converging on a New Theoretical Foundation for Selling." Journal of Marketing 82 (2): 1-18.

Heracleous, Loizos and Michael Barret. 2001. "Organizational Change as a Discourse: Communicative Actions and Deep Structures in the Context of Information Technology Implementation." Academy of Management Journal 44 (4): 755-778. 
Hohenberg, Sebastian and Christian Homburg. 2016. "Motivating Sales Reps for Innovation Selling in Different Cultures." Journal of Marketing 80 (2): 101-120.

Homburg, Christian and Ove Jensen. 2007. "The Thought Worlds of Marketing and Sales: Which Differences Make a Difference?" Journal of Marketing 71 (3): 124-42.

Homburg, Christian, Danijel Jozic, and Christina Kuehnl. 2017. "Customer Experience Management: Toward Implementing an Evolving Marketing Concept." Journal of the Academy of Marketing Science. 45 (3): 377-401.

Homburg, Christian, Jan Wieseke and Christina Kuehnl. 2010. "Social Influence on Salespeople's Adoption of Sales Technology: A Multilevel Analysis." Journal of the Academy of Marketing Science 38 (2): 159-168.

Hunter, Gary K. and William D. Perreault Jr. 2006. "Sales Technology Orientation, Information Effectiveness, and Sales Performance.” Journal of Personal Selling \& Sales Management 26 (2): 95-113.

Hunter, Gary K. and William D. Perreault, Jr. 2007. "Making Sales Technology Effective." Journal of Marketing 71 (1): 16-34.

Honeycutt, Earl D., Jr. 2005. “Technology Improves Sales Performance Doesn’t It? An Introduction to the Special Issue on Selling and Sales Technology." Industrial Marketing Management 34 (3): 301-304.

Hurley, Kevin. 2017. 11 Artificial Intelligence Tools Transforming the B2B Sales World, https://nudge.ai/artificial-intelligence-sales-tools/, Accessed on 10/01/2018.

Järvinen, Joel and Heini Taiminen. 2016. "Harnessing Marketing Automation for B2B Content Marketing." Industrial Marketing Management 54:164-175.

Jasmand, Claudia, Vera Blazevic, and Ko De Ruyter. 2012. "Generating Sales While Providing Service: A Study of Customer Service Representatives' Ambidextrous Behavior." Journal of Marketing 76 (1): 20-37.

Jelinek, Ronald. 2013. “All Pain, No Gain? Why Adopting Salesforce Automation Tools is Insufficient for Performance Improvement.” Business Horizons 56 (5): 635-642.

John Deere. 2018. "Precision Ag Technology." Available at https://www.deere.com/en/technology-products/precision-ag-technology/, accessed on $11 / 06 / 2018$.

Johnson, Michael D. and Fred Selnes. 2004. "Customer Portfolio Management: Toward a Dynamic Theory of Exchange Relationships.” Journal of Marketing 68 (2): 1-17. 
Jones, Eli, Steven P. Brown, Andris A. Zoltners, and Barton A. Weitz. 2005. "The Changing Environment of Selling and Sales Management." Journal of Personal Selling \& Sales Management 25 (2): 105-11.

JOYai. 2018. "Personalized Selling At Scale.” Available at https://www.joyai.com/, accessed on $11 / 06 / 2018$.

Kotler, Philip, Bobby J. Calder, Edward C. Malthouse and Peter J. Korsten. 2012. "The Gap between the Vision for Marketing and Reality." MIT Sloan Management Review 54 (1): 13-14.

Kozinets, Robert V., Kristine De Valck, Andrea C. Wojnicki, and Sarah J. Wilner. 2010. "Networked Narratives: Understanding Word-of-Mouth Marketing in Online Communities." Journal of Marketing 74 (2): 71-89.

Krush, Michael, Ravipreet Sohi, and Amit Saini. 2015. "Dispersion of Marketing Capabilities: Impact on Marketing's Influence and Business Unit Outcomes." Journal of the Academy of Marketing Science 43 (1): 32-51.

Lado, Augustine A. and Michael J. Zhang. 1998. "Expert Systems, Knowledge Development and Utilization, and Sustained Competitive Advantage: A Resource-based Model." Journal of Management 24 (4): 489-509.

Le Meunier-FitzHugh, Kenneth and Tony Douglas. 2016. Achieving a Strategic Sales Focus, Oxford: Oxford University Press.

Leigh, Thomas W, Thomas E. De Carlo, David Allbright and James Lollar. 2014. "Salesperson Knowledge Distinctions and Sales Performance." Journal of Personal Selling \& Sales Management 34 (2): 123-140.

Lindgreen, Adam, Martin K. Hingley, David B. Grant, and Robert E. Morgan. 2012. "Value in Business and Industrial Marketing: Past, Present, and Future." Industrial Marketing Management 41 (1): 207-214.

Limbu, Yam. B., C. Jayachandran and Barry, J. Babin. 2014. "Does Information and Communication Technology Improve Job Satisfaction? The Moderating Role of Sales Technology Orientation.” Industrial Marketing Management 43 (7): 1236-1245.

Loring, Evan. 2018. How AI Will Help Sales Representatives, https://readwrite.com/2018/09/27/how-ai-will-help-sales-representatives/, Accessed on 10/01/2018.

MacDonald, Emma K., Michael Kleinaltenkamp and Hugh N. Wilson. 2016. "How Business Customers Judge Solutions: Solution Quality and Value in Use."Journal of Marketing 80 (3): 96-120. 
Malshe, Avinash, Jeff S. Johnson, and Paul Viio. 2017. "Understanding the Sales-Marketing Interface Dysfunction Experience in Business-to-Business Firms: A Matter of Perspective." Industrial Marketing Management 63 (May): 145-157.

Malshe, Avinash and Ravipreet Sohi. 2009a. "What Makes Strategy Making across the SalesMarketing Interface More Successful?" Journal of the Academy of Marketing Science 37 (4): 400-421.

Malshe, Avinash and Ravipreet S. Sohi. 2009b. "Sales Buy-in of Marketing Strategies: Exploration of Its Nuances, Antecedents, and Contextual Conditions." Journal of Personal Selling \& Sales Management 29 (3): 207-25.

Malthouse, E. C., Haenlein, M., Skiera, B., Wege, E., \& Zhang, M. 2013. "Managing Customer Relationships in the Social Media Era: Introducing the social CRM house." Journal of Interactive Marketing 27 (4): 270-280.

Mariadoss, Babu. J., Chad Milewicz, Sangwon Lee and Avin Sahaym. 2014. "Salesperson Competitive Intelligence and Performance: The Role of Product Knowledge and Sales Force Automation Usage.” Industrial Marketing Management 43 (1): 136-145.

Marks, Michelle A., John E. Mathieu, and Stephen J. Zaccaro. 2001. "A Temporally Based Framework and Taxonomy of Team Processes." Academy of Management Review 26 (3): 356-76.

Marshall, Greg, William Moncrief, John Rudd and Nick Lee. 2012. "Revolution in Sales: The Impact of Social Media and Related Technology in the Selling Environment." Journal of Personal Selling and Sales Management. 32 (3): 349-363

Mathieu, John, M. Travis Maynard, Tammy Rapp, and Lucy Gilson. 2008. "Team Effectiveness 1997-2007: A Review of Recent Advancements and a Glimpse into the Future." Journal of Management 34 (3): 410-476.

Mata, Francisco. J., William L. Fuerst, and Jay B. Barney. 1995. "Information Technology and Sustained Competitive Advantage: A Resource-based Analysis.” MIS Quarterly 19 (4): 487-505.

Mattersight. 2018. "Predictive Behavioral Routing." Available at https://www.mattersight.com/products/predictive-behavioral-routing/, accessed on $11 / 06 / 2018$.

Melas, Ioannis. 2018. Harnessing the Power of Digital Selling. Ernst \& Young. "New Business Trends in Information Technology." Available at https://www.salesforce.com/research/itinnovation-new-biz-trend/, Accessed on 10/2/2018.

McFarland, Richard G., Goutam N. Challagalla and Tasadduq A. Shervani. 2006. "Influence Tactics for Effective Adaptive Selling." Journal of Marketing 70 (4): 103-117. 
Michaelidou, Nina, Nikoletta Theofania Siamagka, and George Christodoulides. 2011. "Usage, Barriers and Measurement of Social Media Marketing: An Exploratory Investigation of Small and Medium B2b Brands." Industrial Marketing Management 40 (7): 1153-1159.

Moncrief, William C. 1986. "Selling Activity and Sales Position Taxonomies for Industrial Salesforces.” Journal of Marketing Research 23 (August): 261-271.

Moncrief, William, C. 2017. "Are Sales as We Know It Dying... Or Merely Transforming?" Journal of Personal Selling \& Sales Management 37 (4): 271-279.

Moncrief, William C., Greg W. Marshall, and Felicia Lassk. 2006. "A Contemporary Taxonomy of Sales Positions.” Journal of Personal Selling and Sales Management 26 (1): 55-65.

Newman, Daniel. 2017. "Innovation vs. Transformation: The Difference in a Digital World." Forbes February 16. https://www.forbes.com/sites/danielnewman/2017/02/16/innovationvs-transformation-the-difference-in-a-digital-world/\#78e90c2265e8, Accessed on $10 / 18 / 2018$.

Orlob, Chris 2017. “Will Your B2B Sales Job Survive AI.” Destination CRM, July 20. https://www.destinationcrm.com/Articles/ReadArticle.aspx?ArticleID=119469, Accessed $11 / 09 / 2018$

Osterloh, Margit and Bruno S. Frey. 2000. "Motivation, Knowledge Transfer, and Organizational Forms." Organization Science 11 (5): 538-550.

Panagopoulos, Nikolaos G., Ryan Mullins, and Panagiotis Avramidis (2018), "Sales Force Downsizing and Firm-Idiosyncratic Risk: The Contingent Role of Investors' Screening and Firm's Signaling Processes," Journal of Marketing, In Press.

Panagopoulos, Nikolaos G., Adam A. Rapp and Jessica L. Ogilvie. 2017. "Salesperson Solution Involvement and Sales Performance: The Contingent Role of Supplier Firm and Customer-Supplier Relationship Characteristics." Journal of Marketing 81 (4): 144-164.

Parsons, McLivaine H. and Greg P. Kearsley. 1982. "Human Factors and Robotics: Current Status and Future Prospects." Human Factors 24 (5): 535-552.

Payne, Adrian, Pennie Frow and Andreas Eggert. 2017. "The Customer Value Proposition: Evolution, Development, and Application in Marketing." Journal of the Academy of Marketing Science 45 (4) :467-489.

Ploetner, Olaf. 2016. "Cost Traps in Business Models 4.0." Available at http://static.esmt.org/publications/whitepapers/Olaf_Ploetner_Brochure_Cost_Traps_en 2016.pdf, accessed on 11/06/2018.

Preston, Andy. Digital Selling (2010) Are You ahead (Or Behind) Your Competition? www.andypreston.com/2010/04/digital-seling-are-you-ahead-or-behind-yourcompetition/, Accessed October 18, 2018. 
Rackham, Neil and John De Vincentis. 1999. Rethinking the Sales Force: Redefining Selling to Create and Capture Customer Value. McGraw Hill-Education.

Ramaswamy, Venkat and Kerimcan Ozcan. 2018. "Offerings as Digitalized Interactive Platforms: A Conceptual Framework and Implications." Journal of Marketing 82 (4): 1931.

Rapp, Adam, Raj Agnihotri, Thomas L. Baker, James 'Mick' Andzulis. 2015. "Competitive Intelligence Collection and Use by Sales and Service Representatives: How Managers' Recognition and Autonomy Moderate Individual Performance." Journal of the Academy of Marketing Science 43 (3): 357-374.

Rapp, Adam A., Daniel G. Bachrach, Karen E. Flaherty, Douglas E. Hughes, Arun Sharma, and Clay M. Voorhees. 2017. "The Role of the Sales-Service Interface and Ambidexterity in the Evolving Organization: A Multilevel Research Agenda." Journal of Service Research 20 (1): 59-75.

Rapp, Adam, Lauren Skinner Beitelspacher, Niels Schillewaert, and Thomas L. Baker. 2012. "The Differing Effects of Technology on inside vs. Outside Sales Forces to Facilitate Enhanced Customer Orientation and Interfunctional Coordination." Journal of Business Research 65 (7): 929-36.

Roe, David. 2017. "Forrester Wave Finds 3 Trends Reshaping Sales Force Automation." Available at https://www.cmswire.com/digital-marketing/forrester-wave-finds-3-trendsreshaping-sales-force-automation/, Accessed on 10/2/2018.

Ross, Jeanne. 2017. "Don't Confuse Digital with Digitization." MIT Sloan Management Review September 29. https://sloanreview.mit.edu/article/dont-confuse-digital-with-digitization/, Accessed on 10/18/2018.

Rouziès, Dominique, Erin Anderson, Ajay K. Kohli, Ronald E. Michaels, Barton A. Weitz, and Andris A. Zoltners. 2005. "Sales and Marketing Integration: A Proposed Framework." Journal of Personal Selling \& Sales Management 25 (2): 113-22.

Showpad. 2018. "Intelligent recommendations for Salesforce." Available at https://www.showpad.com/product/content-recommendations, accessed on 11/06/2018.

Sleep, Stefan, Sundar Bharadwaj, and Son K. Lam. 2015. "Walking a Tightrope: The Joint Impact of Customer and Within-firm Boundary Spanning Activities on Perceived Customer Satisfaction and Team Performance." Journal of the Academy of Marketing Science 43 (4): 472-489.

Singh, Jagdip and Rama K. Jayanti. 2013. "When Institutional Work Backfires: Organizational Control of Professional Work in the Pharmaceutical Industry." The Journal of Management Studies 50 (5): 699-962. 
Speier, Cheri and Viswanath Venkatesh. 2002. "The Hidden Minefields in the Adoption of Sales Force Automation Technologies." Journal of Marketing 66 (July): 98-111.

Srivastava, Rajenda K., Tasadduq A. Shervani, and Liam Fahey. 1998. "Market-Based Assets and Shareholder Value: A Framework for Analysis." Journal of Marketing 62 (1): 2-18.

Syam, Niladri and Arun Sharma. 2018. "Waiting for a Sales Renaissance in the Fourth Industrial Revolution: Machine Learning and Artificial Intelligence in Sales Research and Practice." Industrial Marketing Management 69 (February): 135-146.

Terho, Harri, Alexander Haas, Andreas Eggert and Wolfgang Ulaga. 2012. "It's almost Like Taking the Sales Out of Selling' - Towards a Conceptualization of Value-Based Selling in Business Markets." Industrial Marketing Management 41 (1): 174-185.

Terho, Harri, Andreas Eggert, Alexander Haas and Wolfgang Ulaga. 2015. "How Sales Strategy Translates into Performance: The Role of Salesperson Customer Orientation and ValueBased Selling." Industrial Marketing Management 45 (February): 12-21.

Thaichon, Park, Jiraporn Surachartkumtonkun, Sara Quach, Scott Weaven, and Robert W Palmatier. 2018. "Hybrid Sales Structures in the Age of E-Commerce." Journal of Personal Selling \& Sales Management 38 (3): 1-26.

Thull, Jeff. 2010. Mastering the Complex Sale. Second Edition. Wiley.

Trailer, Barry 2017. “There's Never Been a Better Time to be in Sales.” CSO Insights. https://www.csoinsights.com/wp-content/uploads/sites/5/2018/04/Perfect-Time-to-Be-inSales.pdf. Accessed 11/09/2018

Tuli, Kapil R, Ajay K Kohli, and Sundar G Bharadwaj. 2007. "Rethinking Customer Solutions: From Product Bundles to Relational Processes." Journal of Marketing 71 (3): 1-17.

Ulaga, Wolfgang and Andreas Eggert. 2006. "Value-Based Differentiation in Business Relationships: Gaining and Sustaining Key Supplier Status." Journal of Marketing 70 (1): 119-136.

Ulaga, Wolfgang and Werner J. Reinartz. 2011. "Hybrid Offerings: How Manufacturing Firms Combine Goods and Services Successfully." Journal of Marketing 75 (6): 5-23.

Verbeke, Willem, Bart Deitz, and Ernst Verwaal. 2011. "Drivers of Sales Performance: A Contemporary Meta-Analysis. Have Salespeople Become Knowledge Brokers?" Journal of the Academy of Marketing Science 39 (3): 407-428.

Virtanen, Tatu, Petri Parvinen and Minna Rollins. 2015. "Complexity of Sales Situation and sales Lead Performance: An Empirical Study in Business-to-business Company." Industrial Marketing Management 45 (February): 49-58. 
Wang, Jinjiang, Laibin Zhang, Lixiang Duan, and Robert X. Gao. 2017. “A New Paradigm of Cloud-Based Predictive Maintenance for Intelligent Manufacturing." Journal of Intelligent Manufacturing 28 (5): 1125-1137.

Wedel, Michel and P. K. Kannan. 2016. "Marketing Analytics for Data-Rich Environments." Journal of Marketing 80 (6): 97-121.

Zoltners, Andris A., Prabhakant Sinha, and Sally E. Lorimer. 2008. "Sales Force Effectiveness: A Framework for Researchers and Practitioners." Journal of Personal Selling \& Sales Management, 28 (2), 115-31. 
Figure 1

Framework for Mapping Sales Research Priorities and Questions Motivated by

Sales Digitization and Artificial Intelligence Technologies

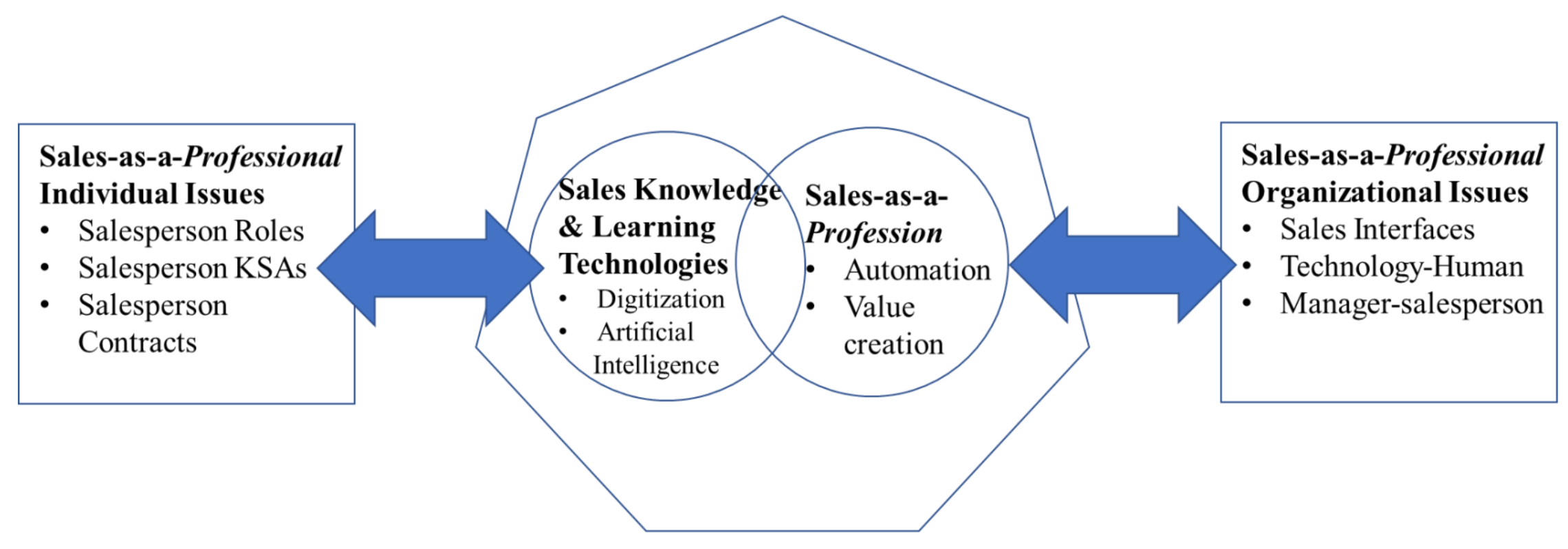


Table 1: Key Definitions for Sales Digitalization, Digitization and AI Technologies

\begin{tabular}{|c|c|c|c|c|}
\hline & $\begin{array}{c}\text { Digital } \\
\text { Transformation }\end{array}$ & Digitalization & $\begin{array}{c}\text { Artificial } \\
\text { Intelligence (AI) }\end{array}$ & Digitization \\
\hline Definition & $\begin{array}{l}\text { Use of digitization } \\
\text { and AI } \\
\text { technologies to } \\
\text { existing company } \\
\text { assets as a means to } \\
\text { improve } \\
\text { competencies and } \\
\text { rethink the value } \\
\text { proposition of the } \\
\text { firm }\end{array}$ & $\begin{array}{l}\text { Use of digitization } \\
\text { and AI technologies } \\
\text { to create new } \\
\text { strategies and } \\
\text { generate novel } \\
\text { opportunities to } \\
\text { serve customers }\end{array}$ & $\begin{array}{l}\text { Learning } \\
\text { (combination of } \\
\text { supervised and } \\
\text { unsupervised) that } \\
\text { permits sales } \\
\text { artifacts (i.e., a } \\
\text { combination of } \\
\text { software, hardware, } \\
\text { and sales protocols) } \\
\text { to perform some or } \\
\text { all of the sales role } \\
\text { autonomously. }\end{array}$ & $\begin{array}{l}\text { Capturing, } \\
\text { processing (e.g., } \\
\text { converting to digits), } \\
\text { and organizing } \\
\text { marketing data (e.g., } \\
\text { sales interactions) to } \\
\text { make it accessible } \\
\text { and reliable for } \\
\text { various goals } \\
\text { including customer } \\
\text { insights, operational } \\
\text { efficiency, customer } \\
\text { analytics, and } \\
\text { marketing learning. }\end{array}$ \\
\hline Implications & $\begin{array}{ll}\text { - } & \text { Increased } \\
& \text { revenues } \\
\text { - } & \text { Increased } \\
& \text { customer value }\end{array}$ & $\begin{array}{l}\text { - Improved } \\
\text { processes } \\
\text { - Enhanced } \\
\text { customer } \\
\text { satisfaction } \\
\end{array}$ & $\begin{array}{l}\text { - Improved } \\
\text { processes } \\
\text { - Reduction in the } \\
\text { need for humans }\end{array}$ & $\begin{array}{l}\text { - Operational } \\
\text { efficiencies } \\
\text { - Data accessibility } \\
\text { and reliability }\end{array}$ \\
\hline Examples & $\begin{array}{l}\text { Redesigning a } \\
\text { firm's customer } \\
\text { service } \\
\text { processes using } \\
\text { AI as a means to } \\
\text { improve the } \\
\text { customer } \\
\text { experience. }\end{array}$ & $\begin{array}{ll}\text { - } & \text { Mobile CRM } \\
\text { - Internet of } \\
\text { Things (IoT) }\end{array}$ & $\begin{array}{l}\text { - Customer Service } \\
\text { Chat-bots } \\
\text { - IBM Watson }\end{array}$ & $\begin{array}{l}\text { - } \text { Customer data } \\
\text { stored in a CRM } \\
\text { system. } \\
\text { - Data analytics }\end{array}$ \\
\hline $\begin{array}{l}\text { Relation to } \\
\text { other } \\
\text { variables }\end{array}$ & $\begin{array}{l}\text { A result of } \\
\text { digitalization. }\end{array}$ & $\begin{array}{l}\text { Facilitates digital } \\
\text { transformation. } \\
\text { Includes } \\
\text { digitization. }\end{array}$ & $\begin{array}{l}\text { A form of } \\
\text { digitalization. }\end{array}$ & $\begin{array}{l}\text { A starting point for } \\
\text { digitalization. }\end{array}$ \\
\hline
\end{tabular}


Table 2: Impact of Knowledge (Digitization) and Learning (AI) Technologies on Sales-as-a -Profession: Value Creation Issues

\begin{tabular}{|c|c|}
\hline Research Question & Research Priorities \\
\hline $\begin{array}{l}\text { How will digitization } \\
\text { and AI technologies } \\
\text { change the knowledge } \\
\text { and learning } \\
\text { processes in the sales } \\
\text { value creation } \\
\text { process? }\end{array}$ & $\begin{array}{l}\text { How effectively can digital technologies process tacit and explicit sales knowledge? Will digital technologies } \\
\text { supplant or supplement salespeople's knowledge capabilities? What are the payoffs and pain points in using digital } \\
\text { technologies to enhance the role of sales knowledge in value creation process? What innovations in digital } \\
\text { technologies are needed to enable its deployment in capturing and using sales knowledge during the value creation } \\
\text { process? } \\
\text { What are the advantages and disadvantages of digital technologies in autonomously learning from sales value } \\
\text { creation process? How can salespeople and digital technologies be configured as an augmented system for } \\
\text { effective sales learning? How will digital technologies enhance the quality and quantity of sales learning for } \\
\text { effective value creation? Under what conditions, and how will digital technologies contribute to enhancing } \\
\text { customer value creation in sales interactions? }\end{array}$ \\
\hline $\begin{array}{l}\text { How will digitization } \\
\text { and AI technologies } \\
\text { change the role of } \\
\text { sales profession in } \\
\text { customer value } \\
\text { creation? }\end{array}$ & $\begin{array}{l}\text { Will digital technologies diminish or amplify the role of sales profession in customer value creation? In B2B } \\
\text { markets? In B2C markets? What business competencies would be important for sales professionals as digital } \\
\text { technologies encroach on the value creation process to absorb recurring as well as sophisticated tasks? How can } \\
\text { the sales profession help its members prepare for these business competencies? } \\
\text { How will information, intelligence and technologies influence the nature and demand for sales profession/function } \\
\text { in organizations and society? Will it be increasingly automated or unlikely to be automated beyond a point? How } \\
\text { will the future of sales profession/function change the nature and background of individuals that are attracted to it? } \\
\text { Does this future hold splintering or consolidation of sales profession/function? } \\
\text { How will the contribution/status of sales profession/function evolve in organizations, for customers they serve, and } \\
\text { in society in general? Will it become more important? Less important? Will it more or less fragmented between } \\
\text { order-takers and knowledge brokers? between low-level lead managers and high-level advisors? }\end{array}$ \\
\hline
\end{tabular}




\begin{tabular}{|l|l|}
\hline $\begin{array}{l}\text { What are the } \\
\text { implications of } \\
\text { digitization and AI } \\
\text { technologies for } \\
\text { skilling and training } \\
\text { individuals for the } \\
\text { sales profession? }\end{array}$ & $\begin{array}{l}\text { How will the deployment of digital technologies affect sales training effectiveness? What sales skills will be in } \\
\text { demand? What skills will be less relevant? Is the bar for performance raised for the entire sales profession with } \\
\text { the introduction of digital technologies? Will the impact of digital technologies on sales training be disruptive or } \\
\text { gradual? }\end{array}$ \\
\hline $\begin{array}{l}\text { How can the sales } \\
\text { profession integrate } \\
\text { digital sales channels } \\
\text { in their value creation } \\
\text { equation? }\end{array}$ & $\begin{array}{l}\text { How will or should salespeople integrate digital sales channels in their selling efforts? how can salespeople convey } \\
\text { the value of digital sales channels to customers, particularly customers who are not digitally savvy? When and } \\
\text { with what success do salespeople promote digital channels to customers? How can companies foster salespeople's } \\
\text { acceptance of digital sales channels as an opportunity for value creation? }\end{array}$ \\
\hline $\begin{array}{l}\text { What digital } \\
\text { technologies are } \\
\text { effective in enhancing } \\
\text { the salesperson's } \\
\text { value creation, for } \\
\text { what kinds of buyers, } \\
\text { and under what } \\
\text { conditions? }\end{array}$ & $\begin{array}{l}\text { Do salespeople create higher value for buyers if they are equipped with intelligence from digital technologies? Are } \\
\text { there segments of salespeople and buyers that benefit more from such insights? In which contexts does } \\
\text { salesperson's intuition outperform digital technologies and vice versa? Which capabilities do salespeople need to } \\
\text { utilize digital technologies effectively? How much leeway should managers give to salespeople to overrule digital } \\
\text { technology based recommendation if experience or intuition suggests otherwise? Will the use of digital } \\
\text { technologies shift value away from customers to suppliers or create an illusion of value through targeted influence } \\
\text { tactics? }\end{array}$ \\
\hline
\end{tabular}


Table 3: Impact of Knowledge (Digitization) and Learning (AI) Technologies on Sales-as-Professionals: Organizational Issues

\begin{tabular}{|c|c|}
\hline Research Question & Research Priorities \\
\hline $\begin{array}{l}\text { How will the infusion } \\
\text { of digitization and AI } \\
\text { technologies influence } \\
\text { the sales structure? }\end{array}$ & $\begin{array}{l}\text { In the changing environment driven by a profusion of technology and artificial intelligence, and the dispersion of } \\
\text { capabilities, how should the future sales organization be structured? What environmental indicators would signal the } \\
\text { use of specialized versus generalized sales roles? Specialized sales roles may be able to deliver more customized } \\
\text { knowledge and customer intelligence, but would it be efficient for the organization? } \\
\text { How would digitization and artificial intelligence change the way customers interact with the organization? How } \\
\text { could this customer interaction be managed? Would this affect the relationship development process? Would we } \\
\text { need new models of relationship development, or could existing models be adapted to reflect these new roles? } \\
\text { What would the tradeoffs be from changing the proportion of inside versus outsides sales roles? Relative to an } \\
\text { outside sales force, to what extent would a larger size or proportion of inside sales roles improve sales performance } \\
\text { and customer outcomes? } \\
\text { How are various stakeholders such as salespeople, sales managers, investors, other organizational divisions, and } \\
\text { customers impacted by changes in the sales force structure? How do strategic decisions to structure the sales force fit } \\
\text { within the marketing or corporate strategies? } \\
\text { With hybrid arrangements and outsourcing of sales capabilities, how should the sales function be managed? How } \\
\text { should firms integrate roles within a hybrid sales organization? How are sales processes changing to coordinate } \\
\text { digital, inside, and outside sales channels? What is the role of sales enablement in supporting the sales organization? } \\
\text { With hybrid arrangements and outsourced sales capabilities, there is a need to understand the intellectual property } \\
\text { issues. Who owns the data? Who owns the relationship? What are the ethical/legal/public policy issues related to } \\
\text { these arrangements? }\end{array}$ \\
\hline $\begin{array}{l}\text { How will the infusion } \\
\text { of digitization and AI } \\
\text { technologies influence } \\
\text { the management of the } \\
\text { sales force? }\end{array}$ & $\begin{array}{l}\text { How will sales organizations measure performance with these new roles and structures? How would salesperson } \\
\text { control change considering high transparency and automation? } \\
\text { Given that more customers are likely to be digitally savvy and early adopters of technology, what new sales skills } \\
\text { will be needed in the future? What type of sales training might be required to provide these skills (e.g., design } \\
\text { thinking, analytics)? }\end{array}$ \\
\hline
\end{tabular}




\begin{tabular}{|c|c|}
\hline $\begin{array}{l}\text { What is the role of } \\
\text { sales teams in the } \\
\text { changing } \\
\text { environment? }\end{array}$ & $\begin{array}{l}\text { How should sales teams be sized and constructed to support customer accounts? How could organizations develop } \\
\text { teams that have people from within the organization and representatives from partners? How would these teams } \\
\text { work with customers to co-create solutions? How would these teams be managed? }\end{array}$ \\
\hline $\begin{array}{l}\text { What is the role of } \\
\text { sales managers in the } \\
\text { changing } \\
\text { environment? }\end{array}$ & $\begin{array}{l}\text { How would the role of the sales manager change in an environment where the salesperson's traditional role and } \\
\text { function are altered by technology and artificial intelligence? Would sales managers have more free time due to } \\
\text { technology and AI, that could be devoted to some areas? If so, what might those areas be? How would their } \\
\text { responsibilities for developing and managing talent change? }\end{array}$ \\
\hline $\begin{array}{l}\text { How will the sales } \\
\text { interfaces be managed } \\
\text { in the changing } \\
\text { environment? }\end{array}$ & $\begin{array}{l}\text { What new competencies will tomorrow's sales organizations possess to handle optimally and benefit from its many } \\
\text { non-marketing interfaces? What factors may determine the sales organization's effectiveness in managing intra and } \\
\text { extra-organizational entities within a complex sales process? How may sales function's experiences in dealing with } \\
\text { their marketing counterparts impact their interactions with other intra-organizational functions? How may sales } \\
\text { function's interactions with non-marketing functions amplify or impede their ability to offer superior customer } \\
\text { value? } \\
\text { Under what conditions may the multi-way flow of information between sales and other intra-organizational entities } \\
\text { be counterproductive in firm's value creation efforts? } \\
\text { What are the benefits and downsides of sales function owning and controlling the flow of customer insights within } \\
\text { the network of intra-organizational entities that are (in)directly involved in the sales process? }\end{array}$ \\
\hline $\begin{array}{l}\text { How will knowledge } \\
\text { be created and utilized } \\
\text { in the changing } \\
\text { environment? }\end{array}$ & $\begin{array}{l}\text { The type of intelligence that individual salespeople need is not always equivalent to the information required by the } \\
\text { organization. How can salespeople be encouraged and train to gather intelligence that will be useful for the } \\
\text { organization as a whole? } \\
\text { How can companies capture market knowledge that resides with customers, channel partners, or is embedded in } \\
\text { networks? How can technology and AI be leveraged to develop market sensing capabilities? How can they be used } \\
\text { to facilitate the conversion of local intelligence to collective intelligence? What competencies may sales } \\
\text { organizations need to develop and leverage customer knowledge that is situated within multiple intra-organizational } \\
\text { functions/entities? } \\
\text { Can companies use social media and other technologies to crowdsource intelligence gathering? Could companies use } \\
\text { crowdsourcing to co-create customer solutions? }\end{array}$ \\
\hline
\end{tabular}


Table 4: Impact of Knowledge (Digitization) and Learning (AI) Technologies on Sales-as-Professionals: Individual Issues

\begin{tabular}{|c|c|}
\hline Research Question & Research Priorities \\
\hline $\begin{array}{l}\text { How will digitization } \\
\text { and AI technologies } \\
\text { influence the sales } \\
\text { process? }\end{array}$ & $\begin{array}{l}\text { To what extent will developments in technology diminish or elevate the importance of certain steps in the traditional } \\
\text { sales process? Will digitization and AI capabilities replace salesperson prospecting? } \\
\text { Can new knowledge and learning be leveraged to benefit lead generation and customer retention? }\end{array}$ \\
\hline $\begin{array}{l}\text { How will digitization } \\
\text { and AI technologies } \\
\text { change the sales role } \\
\text { and required sales } \\
\text { skills? }\end{array}$ & $\begin{array}{l}\text { How far will digitization polarize the sales role? Will sales jobs shift to mundane roles that do not require specialist } \\
\text { skills and abilities, or free the salesperson to develop the higher level, soft skills of connectivity using emotional } \\
\text { intelligence to meet customers' needs? } \\
\text { To what extent can digitization and AI be leveraged to support customer orientation? Will their effects vary in terms } \\
\text { of effective relationship development in the short-term versus long-term? Is AI limited to a focus on customer } \\
\text { expressed needs, rather than building customer stewardship and concern for the customer's overall well-being? }\end{array}$ \\
\hline $\begin{array}{l}\text { What are the effects of } \\
\text { digitization and AI } \\
\text { technologies on } \\
\text { salespeople's cognitive } \\
\text { and professional } \\
\text { development? }\end{array}$ & $\begin{array}{l}\text { To what extent will AI affect individual performance differences? Could AI assistance standardize sales } \\
\text { performance and make the average salespeople look above average? } \\
\text { How do different forms of connectivity (social media) and analysis (bid data analysis) and AI offer opportunities to } \\
\text { the salesperson to develop greater adaptability in their customer interactions? }\end{array}$ \\
\hline $\begin{array}{l}\text { How will digitization } \\
\text { and AI technologies } \\
\text { influence salespeople's } \\
\text { interactions with } \\
\text { customers? }\end{array}$ & $\begin{array}{l}\text { What are the effects of Social Media, Digitization and AI on altering the nature of salespeople's interactions with } \\
\text { customers? How far can social media substitute for face-to-face interactions with customers? Will the development } \\
\text { of AI and social media interactions lead to the development of customer insights that can enhance trust and } \\
\text { emotional connectivity between the salesperson and customer? } \\
\text { To what extent will the role of the salesperson broaden to encompass touchpoint management (e.g., managing the } \\
\text { customer experience by aligning with other important touchpoints within the organization)? }\end{array}$ \\
\hline $\begin{array}{l}\text { What are the effects of } \\
\text { digitization and AI } \\
\text { technologies on } \\
\text { salesperson's } \\
\text { knowledge and } \\
\text { performance? }\end{array}$ & $\begin{array}{l}\text { Will digitization and AI applications in sales increase or decrease the variance in individual level performance? } \\
\text { How will digitization and AI impact salesperson efficiency? What contingencies influence the collaboration of } \\
\text { salespeople during AI implementation? } \\
\text { How will top performing salespeople react to the codification of their tacit knowledge and what could influence this } \\
\text { reaction? Does AI lead to knowledge transfer among salespeople in the same organization? }\end{array}$ \\
\hline
\end{tabular}




\begin{tabular}{|l|l|}
\hline $\begin{array}{l}\text { How, and under what } \\
\text { conditions, will } \\
\text { digitization and AI } \\
\text { technologies benefit } \\
\text { individual salespeople? }\end{array}$ & $\begin{array}{l}\text { What profile of salespeople will benefit the most from AI? Will AI undermine or enhance salesperson self-efficacy? } \\
\text { specific generation play in the adoption of AI? How does AI impact retention or turnover? }\end{array}$ \\
\hline $\begin{array}{l}\text { How will buyers react } \\
\text { to salesperson who is } \\
\text { backed by digitization } \\
\text { and AI technologies? }\end{array}$ & $\begin{array}{l}\text { Are all levels of AI and digitization beneficial to buyer-seller relationships? What types of buyers will benefit the } \\
\text { most from digitization and AI implementation in sales? }\end{array}$ \\
\hline
\end{tabular}

